\title{
Conversion from Positive to Negative EGFR Mutation due to Clonal Selection during Long-Term Treatment with Epidermal Growth Factor Receptor- Tyrosine Kinase Inhibitors: A Case Report
}

\author{
Masatomo Ueda ${ }^{a}$ Masashi Namba $^{b}$ Kentaro Tokumo ${ }^{b}$ Tadashi Senoo $^{c}$ \\ Wataru Okamoto $^{d}$ Masami Yamauchi $^{\mathrm{b}}$ Noboru Hattori ${ }^{\mathrm{e}}$ \\ Kazuhiko Sugiyamab, d \\ aPostgraduate Clinical Training Center, Hiroshima University Hospital, Hiroshima, Japan; \\ ${ }^{b}$ Department of Clinical Oncology, Hiroshima University Hospital, Hiroshima, Japan; \\ 'Department of Respiratory Medicine, National Hospital Organization, Kure Medical Center, \\ Hiroshima, Japan; 'Cancer Treatment Center, Hiroshima University Hospital, Hiroshima, \\ Japan; eDepartment of Respiratory Medicine, Hiroshima University Hospital, Hiroshima, \\ Japan
}

Keywords

Epidermal growth factor receptor mutation - Gefitinib · Erlotinib - Non-small cell lung cancer . Mechanisms of resistance

\section{Abstract}

A 77-year-old woman with postoperative recurrent non-small cell lung adenocarcinoma, which exhibited an epidermal growth factor receptor (EGFR) L858R mutation, was treated with gefitinib and erlotinib. Seven years after the start of treatment, the patient experienced a recurrence of malignant pleural effusion. However, 3 different genetic tests revealed that the lung adenocarcinoma cells in the pleural effusion had lost EGFR L858R mutation, suggesting that long-term treatment with EGFR-tyrosine kinase inhibitors (TKIs) converted EGFR mutation from positive to negative. The negative conversion of EGFR mutation as a mechanism of acquired resistance to EGFR-TKIs is considered rare and needs to be further investigated. 


\section{Introduction}

Patients with epidermal growth factor receptor (EGFR)-mutant lung cancer develop acquired resistance to EGFR-tyrosine kinase inhibitors (TKIs) within a year [1-3], despite an initial good response to EGFR-TKIs. Some possible mechanisms for acquired resistance, such as EGFR T790M or MET amplification [4], have been identified, but there are only a few reports that suggest negative conversion of EGFR mutation as a cause of resistance [5, 6]. Herein, we report the case of a patient with EGFR-mutant lung adenocarcinoma who experienced loss of EGFR L858R mutation after 7 years of EGFR-TKI therapy.

\section{Case Report}

A 77-year-old Japanese woman underwent upper lobectomy of the left lung for lung adenocarcinoma (cT1N0M0 stage IA) in 2004. In 2009, she received chemoradiotherapy (carboplatin + docetaxel, 70 Gy in 28 fractions) because of postoperative recurrence. In 2012, positron emission tomography scans showed an increasing consolidation in the right middle lobe, which indicated a recurrence of lung cancer (Fig. 1A). Genetic analysis showed that the surgically resected specimen had an EGFR L858R mutation, and she was treated with gefitinib (250 mg/day) and achieved a partial response.

In 2017, during treatment with gefitinib without recurrence of lung cancer, CT scans showed a mass in the stomach (Fig. 1B), which was diagnosed as a gastrointestinal stromal tumor (GIST). The patient underwent proximal gastrectomy. In March 2019, multiple low-density areas appeared and were diagnosed as liver metastases of GIST by liver biopsy (Fig. 1C, D). She was subsequently referred to our hospital for chemotherapy.

In April 2019, imatinib (300 mg/day) was started for multiple liver metastases of GIST while remaining on gefitinib (250 mg/day) for lung cancer. In July 2019, gefitinib was replaced with erlotinib $(100 \mathrm{mg} /$ day) because she presented with grade 3 (Common Terminology Criteria for Adverse Events version 5.0) diarrhea following an interaction between gefitinib and imatinib. In January 2020, CT scans showed increased right lung consolidation and pleural effusion, although multiple liver metastases of GIST continued to shrink (Fig. 1E, F), and the patient's carcinoembryonic antigen level increased. She had progressive lung cancer, although multiple liver metastases of GIST were controlled. Erlotinib was discontinued, and gefitinib was re-started because the patient refused to receive cytotoxic agents. She continued gefitinib and imatinib treatment without any side effects. However, lung cancer has progressed, and fatigue and anorexia have worsened.

We suspected the appearance of EGFR T790M mutation and submitted a plasma EGFR mutation test (Cobas ${ }^{\circledR}$ EGFR mutation test version 2.0) in March. Both EGFR L858R, which was originally positive, and T790M mutations were negative. To eliminate the possibility of false-negative results, we submitted pleural fluid that was pathologically diagnosed as adenocarcinoma cells for an EGFR mutation test (peptide nucleic acid-locked nucleic acid polymerase chain reaction [PCR] clamp). However, EGFR mutations were not detected. Subsequently, we prepared a cell block from the pleural fluid specimens (Fig. 2) and submitted it for an EGFR mutation test (Cobas ${ }^{\circledR}$ EGFR mutation test version 2.0), but the results were similar (Table 1 ).

The patient's performance status decreased, and she and her family wanted the best supportive care. Therefore, she discontinued both gefitinib and imatinib and died approximately 1 month later.

\section{Karger'}



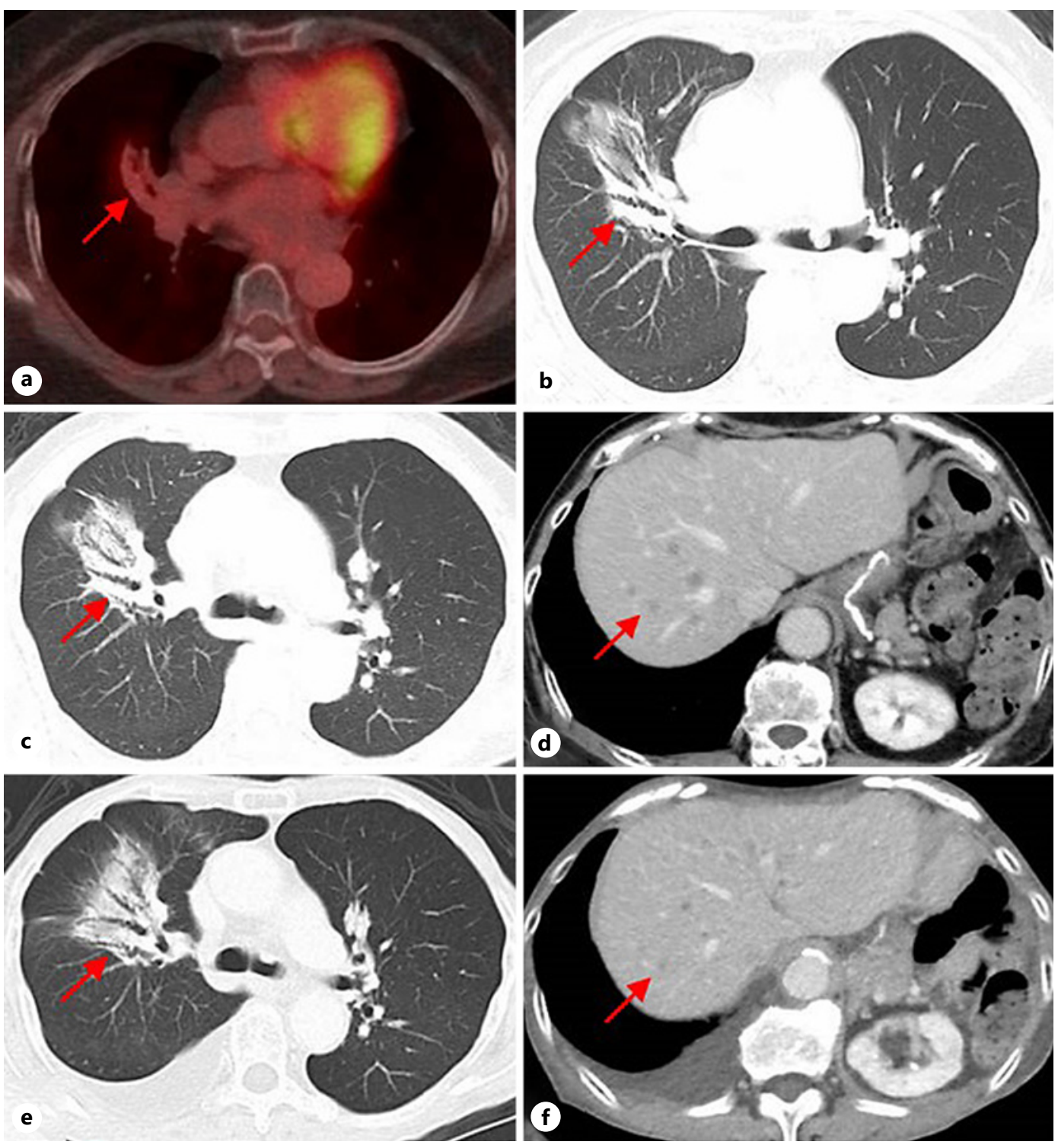

Fig. 1. Lung cancer and GIST in CT images. A PET scans showed bronchocentric consolidation on the right middle lobe in 2012. B Consolidation on the right middle lobe had not changed since 2012, when she was diagnosed with GIST in 2017. In April 2019, consolidation on the right middle lobe had not changed (C), and multiple low-density areas of the liver appeared (D). In January 2020, consolidation on the right middle lobe had increased and pleural effusion emerged (E), while liver metastases of GIST had continued to shrink (F). GIST, gastrointestinal stromal tumor; PET, positron emission tomography.

\section{Discussion}

This patient was treated with EGFR-TKI for postoperative recurrence of EGFR L858Rmutant lung adenocarcinoma and maintained a partial response for approximately 7 years. Finally, it became refractory to EGFR-TKI; thus, we suspected the emergence of the T790M mutation and performed the EGFR mutation test 3 times with different modalities. However, EGFR mutation was negative.

We performed 3 different EGFR mutation tests after the patient became refractory to EGFR-TKIs. Currently, there are 2 main types of EGFR mutation tests: plasma-based tests 


\section{Case Reports in Oncology}

\begin{tabular}{l|l}
\hline Case Rep Oncol 2021;14:1447-1453 \\
\hline DOI: 10.1159/000518246 & $\begin{array}{l}\text { @ 2021 The Author(s). Published by S. Karger AG, Basel } \\
\text { www.karger.com/cro }\end{array}$ \\
\hline
\end{tabular}

Ueda et al.: Negative Conversion of EGFR Mutation during Long-Term EGFR-TKI Treatment

Fig. 2. Cell block of adenocarcinoma cells from pleural fluid specimens. Immunostaining showed that thyroid transcription factor-1 and napsin A were positive, P40 and CK5/CK6 were negative, and programmed death-ligand 1 expression (tumor proportion score) was $0 \%$. CK, cytokeratin.

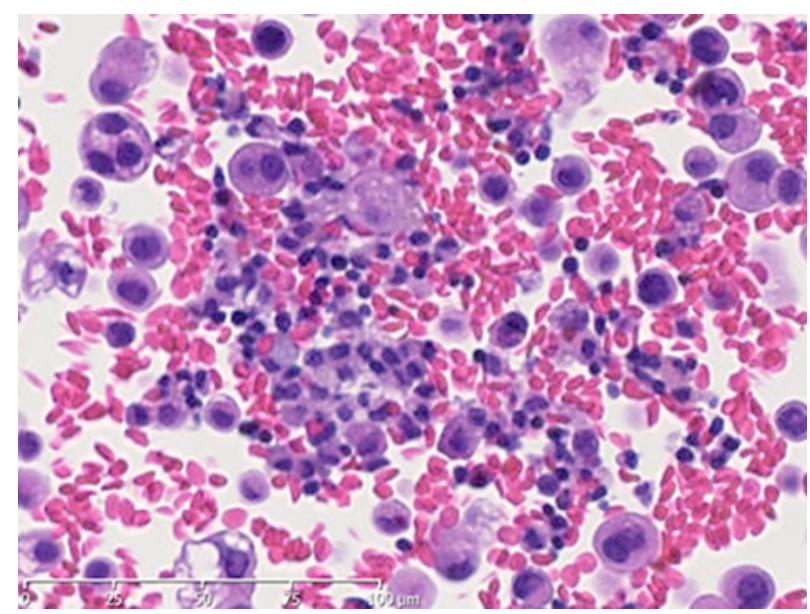

Table 1. EGFR mutation tests performed during the course of the disease

\begin{tabular}{|c|c|c|c|c|}
\hline & Daytime & Specimen & Method & EGFR mutation \\
\hline $\begin{array}{l}\text { Before EGFR-TKI } \\
\text { administration }\end{array}$ & January 2004 & $\begin{array}{l}\text { Tumor tissue } \\
\text { surgically resected }\end{array}$ & PCR - Invader & L858R \\
\hline \multirow[t]{3}{*}{$\begin{array}{l}\text { After EGFR-TKI } \\
\text { administration }\end{array}$} & March 2020 & Plasma & $\begin{array}{l}\text { Cobas }^{\circledR} \text { EGFR mutation } \\
\text { test version } 2.0\end{array}$ & All negative \\
\hline & April 2020 & Pleural fluid & $\begin{array}{l}\text { Peptide nucleic acid- } \\
\text { locked nucleic acid } \\
\text { PCR clamp }\end{array}$ & All negative \\
\hline & & $\begin{array}{l}\text { Cell block made from the } \\
\text { pleural fluid specimens }\end{array}$ & $\begin{array}{l}\text { Cobas }{ }^{\circledR} \text { EGFR mutation } \\
\text { test version } 2.0\end{array}$ & All negative \\
\hline
\end{tabular}

EGFR, epidermal growth factor receptor; TKI, tyrosine kinase inhibitor; PCR, polymerase chain reaction.

and tissue-based tests. It has been reported that the sensitivity of the Cobas plasma test (Cobas ${ }^{\circledR}$ EGFR mutation test version 2.0) is approximately $76.7 \%$ compared to the Cobas tissue test (Cobas ${ }^{\circledR}$ EGFR mutation test version 2.0 ) and approximately $90 \%$ compared to the next-generation sequencing using plasma samples [7]. Therefore, if the plasma test is negative, some cases will be re-tested with a tissue sample to rule out a false-negative result. The Cobas tissue test, in which the minimum detection sensitivity for the EGFR L858R mutation is approximately 4\% [7], was reported to be slightly more accurate than the PCR clamp test [8]. Thus, we performed a Cobas tissue test using cell blocks after performing the PCR clamp test as a third test. Considering that the 3 different tests were all negative, we concluded that the lung adenocarcinoma at the time of recurrence was truly negative for EGFR mutation.

In our case, conversion from EGFR L858R mutation to wild-type EGFR was considered to be the main cause of disease progression to EGFR-TKIs. The main mechanisms of resistance to EGFR-TKIs are EGFR T790M mutation, MET amplification, HER2 amplification, and small cell lung cancer transformation [4, 5, 9]. Although we did not investigate other resistance mechanisms, such as MET amplification, except EGFR T790M, it is certain that EGFR mutations are retained when these known acquired resistances occur [6]. Therefore, we considered that the negative conversion of $E G F R$ mutations may play a critical role in disease progression. 
Table 2. Case series of loss of EGFR mutation

\begin{tabular}{|c|c|c|c|c|c|}
\hline Age and sex & Pathology & EGFR mutation & $\begin{array}{l}\text { Anticancer drugs used } \\
\text { until loss of } E G F R \\
\text { mutation }\end{array}$ & $\begin{array}{l}\text { Time to } \\
\text { treatment } \\
\text { failure }\end{array}$ & References \\
\hline 49 yr, male & Adenocarcinoma & L858R & Gefitinib & 7 months & [6] \\
\hline $34 \mathrm{yr}$, female & $\begin{array}{l}\text { Large cell } \\
\text { carcinoma }\end{array}$ & $\begin{array}{l}\text { Exon19 deletion } \\
\text { (L747-T751) }\end{array}$ & $\begin{array}{l}\text { Cisplatin + docetaxel } \\
\text { Pemetrexed } \\
\text { Gefitinib ( } 250 \mathrm{mg} / \text { body) } \\
\text { Erlotinib ( } 150 \mathrm{mg} / \text { body) } \\
\text { Irinotecan + amrubicin }\end{array}$ & 3 months & {$[11]$} \\
\hline $30 \mathrm{yr}$, female & Adenocarcinoma & L858R, Q787Q & $\begin{array}{l}\text { Cisplatin + pemetrexed } \\
\text { Erlotinib (150 mg/body) }\end{array}$ & 34 months & [12] \\
\hline 87 yr, male & Adenocarcinoma & Exon19 deletion & Gefitinib (250 mg/body) & 9 months & [13] \\
\hline $89 \mathrm{yr}$, female & Adenocarcinoma & L858R & $\begin{array}{l}\text { EGFR-TKI } \\
\text { (drug unknown) }\end{array}$ & 9 months & [14] \\
\hline $77 \mathrm{yr}$, male & Adenocarcinoma & L858R & $\begin{array}{l}\text { Gefitinib ( } 250 \mathrm{mg} / \text { body) } \\
\text { Erlotinib (100 mg/body) }\end{array}$ & 94 months & This case \\
\hline
\end{tabular}

Approximately $15-20 \%$ of acquired resistance remains unknown; negative conversion of EGFR mutations has been reported in a small number of cases $[5,9,10]$. Ji et al. [6] reported that 1 patient showed loss of EGFR mutation in a pathological review of tissues from 25 patients who responded well to gefitinib and later became refractory to treatment. To the best of our knowledge, there are 5 case reports with detailed medical records $[6,11-14]$ (Table 2). The duration of EGFR-TKI treatment ranged from 3 to 34 months in these reports, and no other reports have shown negative conversion of EGFR mutations after long-term EGFR-TKI exposure, as in our case.

In our case, it is possible that long-term treatment with EGFR-TKIs resulted in selective growth of EGFR mutation-negative tumor cells due to genetic heterogeneity in the tumor tissue. Bai et al. [10] reported that there was intratumor heterogeneity of EGFR mutations in approximately $62 \%$ of $E G F R$ mutation-positive non-small cell lung carcinoma. Furthermore, chemotherapy resulted in negative conversion of EGFR mutations. Therefore, in this case report, long-term treatment with EGFR-TKIs eliminated EGFR mutation-positive cells, but only EGFR mutation-negative cells survived selectively, leading to recurrence in the form of increased pleural effusion. In contrary, the possibility of another lung cancer without EGFR mutation should also be considered as 7 years have passed since the start of EGFR-TKIs; however, it seems that this possibility is low because the foci in the lung fields at the time of treatment initiation and recurrence were the same.

In conclusion, this case report demonstrated that the conversion from positive to negative EGFR mutation is one of the causes of acquired resistance to EGFR-TKIs. Clonal selection due to long-term administration of EGFR-TKIs for lung cancer with genetic heterogeneity was considered to be the cause of the negative conversion. The mechanism of negative conversion of EGFR mutations needs to be further investigated.

\section{Acknowledgment}

We would like to thank Editage (www.editage.com) for English language editing.

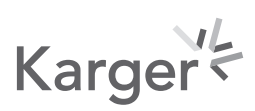




\section{Case Reports in Oncology}

\begin{tabular}{l|l}
\hline Case Rep Oncol 2021;14:1447-1453 \\
\hline DOI: 10.1159/000518246 & $\begin{array}{l}\text { @ 2021 The Author(s). Published by S. Karger AG, Basel } \\
\text { www.karger.com/cro }\end{array}$ \\
\hline
\end{tabular}

Ueda et al.: Negative Conversion of EGFR Mutation during Long-Term EGFR-TKI Treatment

\section{Statement of Ethics}

The study is exempt from ethics committee approval due to only one case report. Written informed consent was obtained from the patient before her death for publication of this case report and any accompanying images.

\section{Conflict of Interest Statement}

The authors declare that they have no conflicts of interest.

\section{Funding Sources}

This study was supported by JSPS KAKENHI (Grant No. 20K17182).

\section{Author Contributions}

All authors contributed to the conception and design of the study. Material preparation and data collection were performed by Masatomo Ueda and Masashi Namba, respectively. The first draft of the manuscript was written by Masatomo Ueda and Masashi Namba. All authors commented on the previous version of the manuscript and approved the final manuscript.

\section{Data Availability Statement}

All the data that support the findings of this study are included in this manuscript.

\section{References}

1 Jackman D, Pao W, Riely GJ, Engelman JA, Kris MG, Jänne PA, et al. Clinical definition of acquired resistance to epidermal growth factor receptor tyrosine kinase inhibitors in non-small-cell lung cancer. J Clin Oncol. 2010 Jan;28(2):357-60.

2 Paez JG, Jänne PA, Lee JC, Tracy S, Greulich H, Gabriel S, et al. EGFR mutations in lung cancer: correlation with clinical response to gefitinib therapy. Science. 2004 Jun;304(5676):1497-500.

3 Maemondo M, Inoue A, Kobayashi K, Sugawara S, Oizumi S, Isobe H, et al. Gefitinib or chemotherapy for non-small-cell lung cancer with mutated EGFR. N Engl J Med. 2010 Jun;362(25):2380-8.

4 Gazdar AF. Epidermal growth factor receptor inhibition in lung cancer: the evolving role of individualized therapy. Cancer Metastasis Rev. 2010 Mar;29(1):37-48.

5 Nosaki K, Satouchi M, Kurata T, Yoshida T, Okamoto I, Katakami N, et al. Re-biopsy status among non-small cell lung cancer patients in Japan: a Retrospective Study. Lung Cancer. 2016 Nov;101:1-8.

6 Ji W, Choi CM, Rho JK, Jang SJ, Park YS, Chun SM, et al. Mechanisms of acquired resistance to EGFR-tyrosine kinase inhibitor in Korean patients with lung cancer. BMC Cancer. 2013 Dec;13:606.

7 Malapelle U, Sirera R, Jantus-Lewintre E, Reclusa P, Calabuig-Fariñas S, Blasco A, et al. Profile of the Roche cobas ${ }^{\circledR}$ EGFR mutation test v2 for non-small cell lung cancer. Expert Rev Mol Diagn. 2017 Mar;17(3):209-15.

8 Ai T, Yuri M, Tabe Y, Kakimoto A, Morishita S, Tsuchiya K, et al. Comparison of the analytical performance between cobas EGFR assay and PCR-clamp method in the detection of EGFR mutations in Japanese non-small cell lung cancer patients. Clin Lab. 2017 May;63(5):1021-6.

9 Yu HA, Arcila ME, Rekhtman N, Sima CS, Zakowski MF, Pao W, et al. Analysis of tumor specimens at the time of acquired resistance to EGFR-TKI therapy in 155 patients with EGFR-mutant lung cancers. Clin Cancer Res. 2013 Apr;19(8):2240-7.

10 Bai H, Wang Z, Chen K, Zhao J, Lee JJ, Wang S, et al. Influence of chemotherapy on EGFR mutation status among patients with non-small-cell lung cancer. J Clin Oncol. 2012 Sep;30(25):3077-83. 
11 Honda Y, Takigawa N, Fushimi S, Ochi N, Kubo T, Ozaki S, et al. Disappearance of an activated EGFR mutation after treatment with EGFR tyrosine kinase inhibitors. Lung Cancer. 2012 Oct;78(1):121-4.

12 Sun Q, Wu JY, Jiao SC. Heterogeneity of epidermal growth factor receptor mutations in lung adenocarcinoma harboring anaplastic lymphoma kinase rearrangements: a case report. Oncol Lett. 2014 Nov;8(5):2093-5.

13 Shiroyama T, Tamiya M, Hayama M, Nishihara T, Nishida T, Tanaka A, et al. A heterochronic genetic change from an EGFR mutation to an ALK rearrangement in a patient with lung adenocarcinoma: a case report. J Thorac Dis. 2016 May;8(5):E345-8.

14 Suda K, Murakami I, Sakai K, Tomizawa K, Mizuuchi H, Sato K, et al. Heterogeneity in resistance mechanisms causes shorter duration of epidermal growth factor receptor kinase inhibitor treatment in lung cancer. Lung Cancer. 2016 Jan; 91:36-40. 